\title{
Effects of the organophosphorus pesticide Folisuper 600 (methyl parathion) on the heart function of bullfrog tadpoles, Lithobates catesbeianus (Shaw, 1802)
}

\author{
M. J. Costa ${ }^{a}$, L. R. Ribeiro ${ }^{a}$, R. F. Salla ${ }^{a}$, F. U. Gamero ${ }^{a}$, L. M. L. M. Alves ${ }^{a}$ and \\ E. C. M. Silva-Zacarin ${ }^{b}$ \\ ${ }^{a}$ Laboratório de Fisiologia da Conservação, Departamento de Biologia, Universidade Federal de São Carlos - UFSCar, \\ Rodovia João Leme dos Santos, SP-264, Km 110, CEP 18052-780, Sorocaba, SP, Brazil

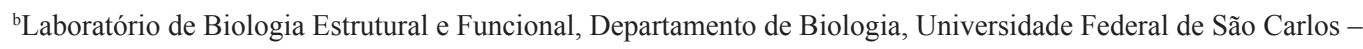 \\ UFSCar, Rodovia João Leme dos Santos, SP-264, Km 110, CEP 18052-780, Sorocaba, SP, Brazil \\ *e-mail: monica@ufscar.br
}

Received: May 12, 2014 - Accepted: September 4, 2014 - Distributed: November 30, 2015

(With 2 figures)

\begin{abstract}
The aim of this work was to evaluate whether the heart function of bullfrog tadpoles ( 25 Gosner stage) is affected by their acute exposure $(48 \mathrm{~h})$ to a sub-lethal concentration $\left(10 \mu \mathrm{g} . \mathrm{L}^{-1}\right)$ of the active principle of the organophosphorus pesticide Folisuper 600R (methyl parathion - MP). Our results demonstrated that MP causes not only a reduction in tadpoles' cardiac ventricular mass, resulting in a marked reduction in their cardiac twitch force, but also impairs their swimming performance, irrespective of increasing their heart rate. Together, these findings indicate that low and realistic concentration of MP have a negative impact on tadpoles' performance, jeopardizing their survival.
\end{abstract}

Keywords: methyl parathion, cardiac performance, bullfrog tadpoles, Lithobates catesbeianus (Rana catesbeiana).

\section{Efeitos do pesticida organofosforado Folisuper 600 (metil paration) sobre a função cardíaca de girinos de rã-touro, Lithobates catesbeianus (Shaw, 1802)}

\section{Resumo}

O objetivo do presente estudo foi avaliar se a função cardíaca de girinos de rãs-touro (estágio 25 de Gosner) é afetada pela exposição aguda $(48 \mathrm{~h})$ a uma concentração sub-letal $\left(10 \mu \mathrm{g} . \mathrm{L}^{-1}\right)$ do princípio ativo do pesticida organofosforado Folisuper 600R (metil paration - MP). Nossos resultados demonstraram que o MP ocasionou não apenas uma redução na massa ventricular cardíaca dos girinos, como também provocou uma redução na sua força de contração cardíaca e de seu desempenho natatório, a despeito de ter sido observado um aumento de sua freqüência cardíaca. Conjuntamente, os achados aqui obtidos indicam que uma baixa e realística concentração de MP exerce um impacto negativo sobre o desempenho dos girinos, ameaçando sua sobrevivência.

Palavras-chave: metil paration, desempenho cardíaco, girinos de rã-touro, Lithobates catesbeianus (Rana Catesbeiana).

\section{Introduction}

Amphibians have been suffering an alarming population decline since the 1970s (Collins and Storfer, 2003). Among the putative causes of this decline are global warming, habitat destruction and/or fragmentation, disease, and also pesticides (Beebee and Griffiths, 2005; Inchaustegui and Powell, 2009; Vieira et al., 2013). In this context, it is important to emphasize that some characteristics, such as amphibians' very permeable skin, make them much more susceptible to anthropogenic changes than other vertebrates, such as the exposure to pollutants (Cowman and Mazanti, 2000; Rowe et al., 2003; Alho, 2008).

Data provided by the Brazilian Department of Environment (Brasil, 2015), indicate that Brazil occupies the first position in the world ranking of countries that use the most agrochemicals. In particular, organophosphorated pesticides (OPs) are consumed on a large scale in several countries, including Brazil, where they are employed to control several types of infestation that harm plant cultures. However, OPs present an elevated toxicity, directly poisoning not only non-target animals but also contaminating the wider aquatic environment (Campagna et al., 2006). Moreover, due to the fact that OPs are liposoluble, these substances present a high potential of bioaccumulation (Cavaliere et al., 1996; Yu et al., 2008).

Despite its high toxicity, methyl parathion ( $\mathrm{MP}-\mathrm{C}_{8} \mathrm{H}_{10} \mathrm{NO}_{5} \mathrm{PS}$ ) continues to be employed without 
restriction and/or supervision for agricultural purposes (e.g., cotton, soybean, corn, barley, sunflower) in Brazil, not only to combat predators in agriculture, but also aquatic weeds. It is available in several commercial formulations as Metaphos, Dalif, Bladan, Cekumethion, E601, Folidol - M, Fosferno M50, Gearphos, Kilex, Parathion, Folisuper $600 \mathrm{BR}$, among others (Edwards and Tchounwou, 2005). However, due to its high toxicity, the use of MP in the US has been restricted to certified industries by the US Environmental Protecting Agency (Edwards and Tchounwou, 2005). In contrast, in developing countries, where neither its sale nor its application are intensively monitored by controlling agencies, MP is consumed without limitation in agriculture and for aquaculture purposes due to its low cost associated to a high efficacy.

Among the negative effects of the exposure of non-target animals to MP (as to other OPs), is its capacity to inhibit the activity of the enzyme acethylcholinesterase (AChE), which is responsible for acetylcholine (ACh) hydrolysis (Rezende, 2006; Monteiro et al., 2009). As a consequence, ACh accumulates in the synaptic cleft. Among the effects of cholinergic overstimulation already described to mammals are tearing, sweating, cardiorespiratory alterations, salivation, changes in the central nervous system, bradycardia, as well as muscle necrosis (Cavaliere et al., 1996; Edwards and Tchounwou, 2005). However, information regarding the effects of exposure to MP and other OPs in amphibians is still scarce (Taylor et al., 1999; Khan et al., 2003). Nevertheless, due to its lipophilic nature, MP can readily penetrate the tegument of non-target organisms, causing a variety of damage to their cellular machinery (Monteiro et al., 2006). Indeed, in aquatic animals the contamination by MP can also be through water ingestion and respiration (Mataqueiro et al., 2008).

Considering the previous observations, in association with the paucity of data about the effects of MP on anurans, the aim of this work was to evaluate whether a sublethal concentration of MP $\left(10 \mu \mathrm{g} . \mathrm{L}^{-1}\right)$ that falls within the concentration range found in the water near agricultural areas in Brazil (Rodrigues and Almeida, 2005) can affect the cardiac physiology of bullfrog tadpoles, Lithobates catesbeianus (Shaw 1802). In this sense, it is worth mentioning that other authors have already proved this endpoint is very sensitive and useful when we intend to notice the negative impact of a sublethal concentration of environmental stressors over an organism before it will cause mortality or other multifactorial deleterious effects that could ultimately result in a wide decline in the population level in mammals (Calore et al., 2007), fish (e.g., Martins et al., 2011; Andrade-Waldemarin et al., 2012), but also in amphibians (e.g., Coşkun et al., 2004; Costa et al., 2008; Dal-Medico et al., 2014).

\section{Material and Methods}

\subsection{Chemicals}

The commercial formulation of the methyl parathion (O,O-dimethyl O-4-nitrophenyl phosphorothioate) Folisuper $600 \mathrm{BR}^{\circledR}$ (methyl parathion $600 \mathrm{~g} \mathrm{~L}^{-1}$ ) from
Agripec Química \& Farmacêutica S/A was used. All the other chemicals and reagents were purchased from Sigma-Aldrich Chemical Co.

\subsection{Animal care}

Newly hatched Lithobates catesbeianus (Shaw 1802) tadpoles were obtained from a breeding colony at Santa Bárbara D'Oeste, Southeast Brazil (2278'S, 4740’W). Tadpoles were housed in $50 \mathrm{~L}$ aquaria equipped with a continuous supply $(1.2 \mathrm{~L} / \mathrm{h})$ of well-aerated and dechlorinated water at a constant temperature $\left(25 \pm 1^{\circ} \mathrm{C}\right)$ and a natural photoperiod $(\sim 12 \mathrm{~h}$ light:dark cycle) until they reached Gosner (1960) developmental stage 25 ( $\sim 1$ week) at the time of MP application. Animals were fed ad libitum with commercial food flakes (Oscar Sticks ${ }^{\circledR}$, Alcon; 35-40\% protein), which was withheld $48 \mathrm{~h}$ before exposure.

\subsection{Experimental design}

During the ecotoxicological experiments, the water was monitored daily to ensure that the physical and chemical parameters were kept at acceptable levels $(\mathrm{pH} 7.2 \pm 0.1$; hardness as $\mathrm{CaCO}_{3} 52 \pm 4 \mathrm{mg} \mathrm{L}{ }^{-1} ; \mathrm{DO}_{2} 7.1 \pm 0.3 \mathrm{mg} \mathrm{L}^{-1}$, conductivity $98.78 \pm 2.32 \mu \mathrm{S} / \mathrm{cm})$, as found in most Brazilian inland waters (CETESB, 2014).

After reaching 25 Gosner stage, the tadpoles (body mass $=2.26 \pm 0.44 \mathrm{~g}$ ) were randomly divided into two triplicated experimental groups: Control Group (CT; $\mathrm{n}=36$ ) and Xenobiotic exposed (MP, $10 \mu \mathrm{g} . \mathrm{L}^{-1}$ of the active ingredient, $\mathrm{n}=36$ ) for $48 \mathrm{~h}$. This concentration was chosen based on the concentration range of MP found in the water near agricultural areas in Brazil, as reported by Rodrigues and Almeida (2005). Given that in aqueous solution MP presents a half life of 120 days in the water (EPA, 1999), it is reasonable to assume that the nominal concentration of this herbicide would not be significantly decreased in the water during the ecotoxicological experiments.

Both experimental groups were placed in 30L glass aquaria filled with dechlorinated well-aerated water $\left(>6.0 \mathrm{mg} \mathrm{O}_{2} \cdot \mathrm{L}^{-1}\right)$, with a controlled temperature $\left(25 \pm 1^{\circ} \mathrm{C}\right)$ on a 12:12 h light: dark cycle. Aquaria were blacked out on the sides to prevent external disturbance. Control and xenobiotic-exposed tadpoles were maintained in these conditions for $48 \mathrm{~h}$ in a static system. All procedures followed ASTM guidelines (ASTM, 2014).

The activity level (AL) of bullfrog tadpoles of both experimental groups was monitored twice a day according to the methodology proposed by Fraker and Smith (2004) for Lithobates pipiens tadpoles. Briefly, "activity" was defined as a constant movement through aquaria, while "inactivity" meant that the animal keeps stationary on the bottom or passively floats.

\subsection{Physiological biomarkers}

After exposure, animals were euthanized by cranial concussion to avoid any side effects on their cardiac physiology (AVMA, 2001). Immediately after euthanasia, in loco heat rate measurements in bullfrog tadpoles were taken on individuals placed in water-filled holding chambers made from Petri dishes. A continuous flow of well-aerated 
physiological solution proper to anuran tadpoles (see below) thermostatized at $25 \pm 1^{\circ} \mathrm{C}$ was maintained throughout the chamber. The celomatic cavity of each individual was surgically opened in a caudal-cranial direction for pericardium exposure. The in loco $f_{\mathrm{H}}$ (basal) was determined visually and expressed as beats per minute (bpm). This procedure provides more reliable data on the basal heart frequency (personal observations), in so far as it avoids the stress that might be caused by the implantation of subcutaneous ECG electrodes in living animals.

After $f_{\mathrm{H}}$ determination, the tadpoles had their hearts dissected, and the ventricle carefully removed. Ventricles were weighed $(\mathrm{Wv})$, and the ventricular mass was expressed as a percentage of the body mass (RVM $-\%$ of $\mathrm{Wb}$ ).

Ventricle strips (diameter $\sim 1 \mathrm{~mm}$; mass $=0.6 \pm 0.1 \mathrm{mg}$; length $=1.1 \pm 0.1 \mathrm{~mm}$ - mean $\pm \mathrm{SE}$ ) were prepared for isometric contraction recordings, following the procedures described by Costa et al. (2008). After stabilization, the twitch force developed by ventricle strips $\left(\mathrm{Fc}-\mathrm{mN} \cdot \mathrm{mm}^{-2}\right)$ was measured as stimulation frequency was increased from $0.2 \mathrm{~Hz}$ up to a frequency at which the muscle failed to show any further regular contractions. The maximal in vitro stimulation frequency was considered the frequency at which at least $80 \%$ of the strips were still able to contract regularly. During this protocol, not only the Fc was measured, but also the cardiac dynamics, i.e., the time to peak tension (TPT $-\mathrm{ms}$ ), and the time to half relaxation (THR - $\mathrm{ms}$ ).

\subsection{Statistical analysis}

Results are presented as means \pm 1 S.E.M. For comparisons between two groups, t- tests (parametric) or Mann-Whitney U-tests (non-parametric) were applied. The Kolmogorov and Smirnov method was applied to evaluate normality of the samples and the F test was applied for homogeneity of variances (GraphPad Instat version 3.00, GraphPad Software, USA). Differences between means at a 5\% $(\mathrm{P}<0.05)$ level were considered significant.

\section{Results}

Mortality was not observed for any experimental group during the ecotoxicological experiments, nor variations between the body mass of CT $(2.15 \pm 0.18 \mathrm{~g})$ and MP $(2.20 \pm 0.13 \mathrm{~g})$ groups with respect to that observed before exposure $(2.26 \pm 0.44 \mathrm{~g})$. The AL in the MP-group $(7 \pm 2 \%)$ was lower $(P<0.05)$ than that observed in the CT-group
$(29 \pm 4 \%)$. In contrast, the heart frequency of the MP-group $(79.5 \pm 0.6 \mathrm{bpm})$ was higher $(P<0.05)$ than that observed in its controls $(66.8 \pm 2.7 \mathrm{bpm})$ (Table 1$)$. This stimulatory effect of MP on the heart frequency could be evidenced in vitro by an acceleration in the cardiac dynamics due to the $30 \%$ reduction $(P<0.05)$ in both TPT and in the THR at most stimulation frequencies, irrespective of the stimulation frequency (Figure 1a, b). Moreover, the reduction $(P<0.05)$ in the relative ventricular mass (Table 1) of MP-exposed tadpoles (from $0.326 \pm 0.017 \%$ in CT-group to $0.081 \pm 0.006 \%$ in MP) was probably the main cause of the $\sim 50 \%$ decrease $(P<0.05)$ in the twitch force $\left(\mathrm{Fc}-\mathrm{mN} \cdot \mathrm{mm}^{-2}\right)$ of the MP-group as compared to the CT-group at all frequency range (Figure 1c), including those observed in loco (arrows at Figure 1). Not only was the Fc lower in the MP-group, but also the maximal frequency at which the ventricle strips retained their capacity to contract regularly $(1.2 \mathrm{~Hz})$ in this group was also lower than in the CT-group.

\section{Discussion}

When faced with adverse conditions, animals can either try to escape from the stressful situation or activate physiological adjustments to counteract the imposed stress. As a consequence, animals display a large variation in cardiac function according to the mode of life and the activity level (Costa et al., 2008). The ability of the cardiac muscle to maintain pump performance under different physiological conditions is one of the most important characteristics that enable vertebrates to survive under adverse conditions (Driedzic and Gesser, 1994). Consequently, efficient adjustments of cardiac output in response to xenobiotics, achieved by changes in stroke volume and/or heart rate are crucial. Cardiac stroke volume is determined by the regulation of myocardial contractility, which depends on the complex regulation of intracellular calcium $\left(\left[\mathrm{Ca}^{2+}\right]_{\mathrm{i}}\right)$ homeostasis on a beat-to-beat basis (Lewartowski and Pytkowski, 1987; Bers, 2001).

Due to its lipophilicity, MP can easily cross cellular membranes, causing chemical and physical disturbances that jeopardize cell homeostasis. In this sense, MP can damage several intracellular organelles (e.g., mitochondria, endoplasmatic reticulum, nuclei), as already observed in the gills of the flounder Paralichthys olivaceus ( $\mathrm{Li}$ and Zhang, 2002).

Table 1. Relative ventricular mass (RVM - \% of body mass), in loco heart rate $\left(f_{\mathrm{H}}-\mathrm{bpm}\right)$, and the activity level (AL - \% of animals) presented by $L$. catesbeianus tadpoles exposed to methyl parathion (MP; $\mathrm{n}=36$ ) in relation to their controls $(\mathrm{CT} ; \mathrm{n}=36)$.

\begin{tabular}{|c|c|c|c|c|c|c|}
\hline \multirow{2}{*}{ Group } & \multicolumn{2}{|c|}{ RVM (\%) } & \multicolumn{2}{|c|}{$f_{\mathrm{H}}(\mathrm{bpm})$} & \multicolumn{2}{|c|}{ AL (\%) } \\
\hline & Mean & SE & Mean & SE & Mean & SE \\
\hline MP & 0.081 & 0.006 & 79.5 & 0.6 & 7 & 2 \\
\hline $\mathrm{CT}$ & 0.326 & 0.017 & 66.8 & 2.7 & 29 & 4 \\
\hline Statistics & \multicolumn{2}{|c|}{$\begin{array}{c}P<0.05 \\
\text { (significant) }\end{array}$} & \multicolumn{2}{|c|}{$\begin{array}{c}P<0.05 \\
\text { (significant) }\end{array}$} & \multicolumn{2}{|c|}{$\begin{array}{c}P<0.05 \\
\text { (significant) }\end{array}$} \\
\hline
\end{tabular}

The results are presented as means \pm SE. The significance levels to each parameter are presented in the last line. 

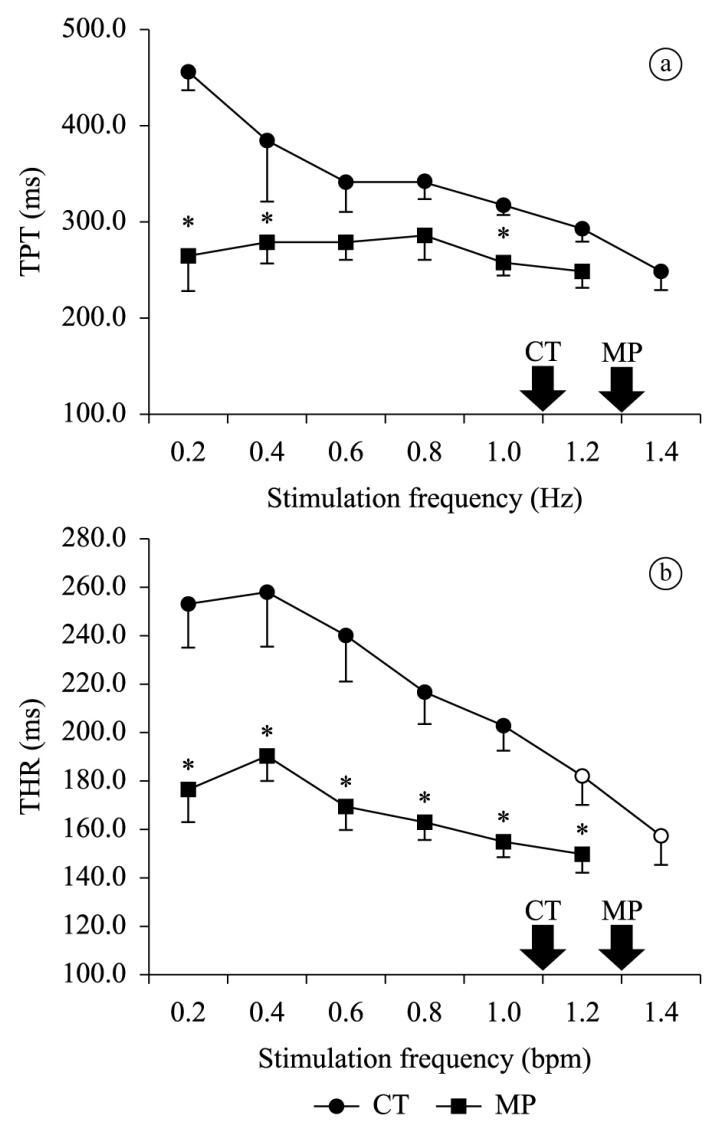

Figure 1. Time to peak tension (TPT $-\mathrm{ms}$ ), and time to half relaxation (THR - ms) developed by ventricle strips of $L$. catesbeinus tadpoles from the control group (CT; $\mathrm{n}=36$ ) and from animals exposed to methyl parathion (MP; $\mathrm{n}=36$ ) during increments of stimulaton frequency. Mean values \pm SE. The asterisks above means denote a significant difference $(\mathrm{P}<0.05)$ in relation to the control. Open symbols denote a difference $(\mathrm{P}<0.05)$ in relation to the initial frequency $(0.2 \mathrm{~Hz})$. The arrows indicate the stimulation frequency measured in loco. Note the different scales for each figure.

Due to the fact that $\mathrm{ACh}$ is not completely hydrolyzed, this process leads to a hyperactivity of the cholinergic system (Araújo et al., 2006). Therefore, the reduction in tadpoles' activity level in response to MP exposure (Table 1) is probably due to the fact that this xenobiotic inhibits AChE activity in the motor end-plate of the skeletal muscle fiber, impairing tadpoles' swimming performance. A decrease in the swimming activity in response to the inhibition of AChE activity was already observed to Jenynsia multidentata (Ballesteros et al., 2009), Oncorhynchus mykiss (Brewer et al., 2001), and to Gambusia affinis (Rao et al., 2005).

However, an effect of the overstimulation of cholinergic system was not observed in the heart of bullfrog tadpoles (Table 1). The absence of a bradycardia is due to the fact that, at 25 Gosner developmental stage, tadpoles' hearts still do

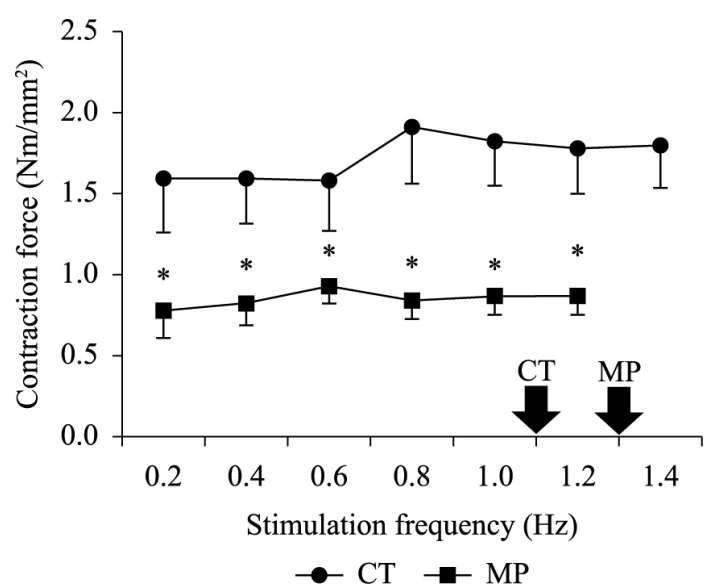

Figure 2. Twitch Force $\left(\mathrm{Fc}-\mathrm{mN} \cdot \mathrm{mm}^{-2}\right)$ developed by ventricle strips of $L$. catesbeinus tadpoles from the control group ( $\mathrm{CT} ; \mathrm{n}=36)$ and from animals exposed to methyl parathion (MP; $n=36$ ) during increments of stimulaton frequency. Mean values $\pm \mathrm{SE}$. The asterisks above means denote a significant difference $(\mathrm{P}<0.05)$ in relation to the control. Open symbols denote a difference $(\mathrm{P}<0.05)$ in relation to the initial frequency $(0.2 \mathrm{~Hz})$. The arrows indicate the stimulation frequency measured in loco.

not present a cholinergic innervation (Protas and Leontieva, 1992). This finding contrasts the results reported by other authors that worked with animals that already presented cholinergic innervation in the heart (Cavaliere et al., 1996; Rezende, 2006; Körbes, 2009). Contrariwise, there was not only an absence of bradycardia, but MP also resulted in an acceleration of heart frequency (Table 1). In this sense, it can be stated that MP exerts a direct effect over the mechanisms that transport $\mathrm{Ca}^{2+}$ through myocyte' cellular membrane (sarcolemma). Therefore, MP can either phosphorylate sarcolemmal L-channels or its $\mathrm{Na}^{+} / \mathrm{Ca}^{2+}$ exchanger. This assertion is supported by the data obtained in vitro, in which the cardiac dynamics (TPT and THR) was accelerated, resulting in a faster contraction-relaxation cycle, especially in the relaxation (Figure 1).

Nevertheless, the twitch force $(\mathrm{Fc})$ of MP-exposed animals was half that observed for controls (Figure 2). This finding is probably correlated to the decrease $(\sim 80 \%)$ in the relative ventricular mass (RVM) of MP-exposed tadpoles (Table 1). Additionally, the faster dynamics of contraction-relaxation cycle may also contribute to the decrease in the $\mathrm{Fc}$ of MP-group, since there is a lower time available for $\mathrm{Ca}^{2+}$-influx and/or efflux to and from the cell if there is not a proportional optimization of $\mathrm{Ca}^{2+}$ transporting mechanisms.

In sum, the results presented and discussed demonstrate that methyl-parathion exerts a negative impact on the cardiac function of bullfrog tadpoles, mainly due to the drastic reduction in the Fc. Nevertheless, the acceleration in the cardiac dynamics in response to MP, despite being a more energy-demanding process than cardiac inotropism, seems to represent a strategy to improve cardiac performance and promote an adequate xenobiotic's detoxification. 


\section{Acknowledgements}

The authors are thankful to the Brazilian Institute of Comparative Physiology (financial support to MJC, CNPq 573921/2008-3 and FAPESP 08/57712-4) and to CNPq (scholarship to LRR). The authors are also very grateful to R. Corcos - University of California, Santa Barbara, CA, U.S - for having conducted a second and careful revision of the English. All procedures were previously approved by the Environmental and Animal Experimentation Ethics Committees of the Federal University of São Carlos (protocols\# CEA 027/2009 and CEEA 051/2010), which are in accordance with Brazilian regulations.

\section{References}

ALHO, C.J.R., 2008. Biodiversity of the Pantanal: response to seasonal flooding regime and to environmental degradation. Brazilian Journal of Biology $=$ Revista Brasileira de Biologia, vol. 68 , no. 4, suppl., pp. 957-966. http://dx.doi.org/10.1590/ S1519-69842008000500005. PMid:19197468.

AMERICAN SOCIETY FOR TESTING AND MATERIALS - ASTM, 2014 [viewed 2 February 2015]. ASTM E1192-97: Standard guide for conducting acute toxicity tests on aqueous ambient samples and effluents with fishes, macroinvertebrates, and amphibians [online]. West Conshohocken: ASTM. Book of Standards, vol. 11.06. Available from: http://www.astm.org/ Standards/E1192.htm

AMERICAN VETERINARY MEDICAL ASSOCIATION AVMA, 2001. Report of the AVMA panel on euthanasia. American Veterinary Medical Association, vol. 218, no. 5, pp. 669-696. http://dx.doi.org/10.2460/javma.2001.218.669. PMid:11280396.

ANDRADE-WALDEMARIN, K.C., ALVES, R.N., BELETTI, M.E., RANTIN, F.T. and KALININ, A.L., 2012. Copper sulfate affects Nile tilapia (Oreochromis niloticus) cardiomyocytes structure and contractile function. Ecotoxicology (London, England), vol. 21, no. 3, pp. 783-794. http://dx.doi.org/10.1007/ s10646-011-0838-3. PMid:22160950.

ARAÚJO, A.J., LIMA, J.S., MOREIRA, J.C., JACOB, S.C., SOARES, M.O., MONTEIRO, M.C.M., AMARAL, A.M., KUBOTA, A., MEYER, A., COSENZA, C.A.N., NEVES, C. and MARKOWITZ, S., 2006. Multiple exposure to pesticides and impacts on health: a cross-section study of 102 rural workers, Nova Friburgo, Rio de Janeiro State, Brazil. Science \& Public Health, vol. 12, no. 1, p. 115-130. http://dx.doi.org/10.1590/S1413-81232007000100015.

BEEBEE, T.J.C. and GRIFFITHS, R.A., 2005. The amphibian decline crisis: a watershed for conservation biology? Biological Conservation, vol. 125, no. 3, pp. 271-285. http://dx.doi. org/10.1016/j.biocon.2005.04.009.

BERS, D.M., 2001. Excitation-contraction coupling and cardiac contractile force. 2nd ed. Dordrecht: Kluwer Academic Publishers.

BRASIL. Ministério Brasileiro do Meio Ambiente-MMA, 2015 [viewed 29 October 2015]. Agrotóxicos [online]. Brasília: MMA. Available from: http://www.mma.gov.br/seguranca-quimica/ agrotoxicos

CALORE, E.E., PEREZ, N.M. and HERMAN, M.M., 2007. Morphometric studies of cardiac myocytes of rats chronically treated with an organophosphate. Ecotoxicology and Environmental
Safety, vol. 66, no. 3, pp. 447-450. http://dx.doi.org/10.1016/j. ecoenv.2006.04.001. PMid:16797706.

CAMPAGNA, A.F., ELER, M.N., ESPÍNDOLA, E.L., SENHORINI, J.A., RÊGO, R.F. and SILVA, L.O., 2006. Dimethoate 40\% organosphosphorous pesticide toxicity in Prochilodus lineatus (Prochilodontidae, Characiformes) eggs and larvae. Brazilian Journal of Biology $=$ Revista Brasileira de Biologia, vol. 66, no. 2B, pp. 633-640. http://dx.doi.org/10.1590/S1519-69842006000400007. PMid:16906295.

CAVALIERE, M.J., CALORE, E.E., PEREZ, N.M. and PUGA, F.R., 1996. Miotoxicidade por organofosforados. Revista de Saúde Pública, vol. 30, no. 3, pp. 267-272.

COMPANHIA AMBIENTAL DO ESTADO DE SÃO PAULO CETESB, 2014 [viewed 26 August 2014]. Variáveis da qualidade das águas superficiais [online]. São Paulo: CETESP. Available from: http://www.cetesb.sp.gov.br/agua/Aguas-Superficiais/ Variaveis-de-Qualidade-das-Aguas

COLLINS, J.P. and STORFER, A., 2003. Global amphibian declines: sorting the hypotheses. Diversity \& Distributions, vol. 9, no. 2, pp. 89-98. http://dx.doi.org/10.1046/j.1472-4642.2003.00012.x.

COȘKUN, B., ÇÖMELEKOĞLU, Ü., POLAT, A., AYS-POLAT, B.C. and FIGEN KAYMAZ, F., 2004. Evaluation of the toxic effects of cypermethrin inhalation on the frog heart. Ecotoxicology and Environmental Safety, vol. 57, no. 2, pp. 220-225. http:// dx.doi.org/10.1016/S0147-6513(03)00029-0. PMid:14759669.

COSTA, M.J., MONTEIRO, D.A., OLIVEIRA-NETO, A.L., RANTIN, F.T. and KALININ, A.L., 2008. Oxidative stress biomarkers and heart function in bullfrog tadpoles exposed to Roundup Original ${ }^{\circledR}$. Ecotoxicology (London, England), vol. 17, no. 3, pp. 153-163. http://dx.doi.org/10.1007/s10646-007-0178-5. PMid:17987383.

COWMAN, D.E. and MAZANTI, L.E., 2000. Ecotoxicology of "new generation" pesticides to amphibians. In: D.W. SPARLING, G. LINDER and C.A. BISHOP, eds. Ecotoxicology of amphibians and reptiles. Pensacola: SETAC Press. 904 p.

DAL-MEDICO, S.E., RISSOLI, R.Z., GAMERO, F.U., VICTÓRIO, J.Á., SALLA, R.F., ABDALLA, F.C., SILVA-ZACARIN, E.C.M., CARVALHO, C.S. and COSTA, M.J., 2014. Negative impact of a cadmium concentration considered environmentally safe in Brazil on the cardiac performance of bullfrog tadpoles. Ecotoxicology and Environmental Safety, vol. 104, pp. 168-174. http://dx.doi. org/10.1016/j.ecoenv.2014.03.003. PMid:24681445.

DRIEDZIC, W.R. and GESSER, H., 1994. Energy metabolism and contractility in ectothermic vertebrate hearts: hypoxia, acidosis, and low temperature. Physiological Reviews, vol. 74, no. 1, pp. 221-258. PMid:8295934.

EDWARDS, F.L. and TCHOUNWOU, P.B., 2005. Environmental toxicology and health effects associated with methyl parathion exposure - a scientific review. International Journal of Environmental Research and Public Health, vol. 2, no. 3-4, pp. 430-441. http:// dx.doi.org/10.3390/ijerph2005030007. PMid:16819098.

ENVIRONMENTAL PROTECTION AGENCY - EPA, 1999. Office of pesticide programs health effects division (7509C). Washington: EPA. 313 p.

FRAKER, S.L. and SMITH, G.R., 2004. Direct and interactive effects of ecologically relevant concentration of organic wastewater contaminants on Rana pipiens tadpoles. Environmental Toxicology, vol. 19, no. 3, pp. 250-256. http://dx.doi.org/10.1002/tox.20017. PMid: 15101040 . 
GOSNER, K.L., 1960. A simple table for staging anuran embryos and larvae with notes on identification. Herpetologica, vol. 10, pp. 1387-1397.

INCHÁUSTEGUI, S.J. and POWELL, R., 2009. Conservation of the herpeto fauna of the Dominican Republic. Applied Herpetology, vol. 6, no. 2, pp. 103-122. http://dx.doi.org/10.1163/157075409X427153.

KHAN, M.Z., TABASSUM, R., NAQVI, S.N.H., SHAH, E.Z., TABASSUM, F., AHMAD, I., FATIMA, F. and KHAN, M.F., 2003. Effect of cypermethrin and permethrin on cholinesterase activity and protein contents in Rana tigrina (Amphibia). Turkish Journal of Zoology, vol. 27, pp. 243-246.

KÖRBES, D., 2009. Toxicity of organophosphorus pesticides in the peripheral auditory system of guinea pigs: anatomical and functional study. Santa Maria: Universidade Federal de Santa Maria, 83 p. Masters Dissertation in Human Communication Disorders.

LEWARTOWSKI, B. and PYTKOWSKI, B., 1987. Cellular mechanisms of the relationship between myocardial force and frequency of contractions. Progress in Biophysics and Molecular Biology, vol. 50, no. 2, pp. 97-120. http://dx.doi.org/10.1016/00796107(87)90005-8. PMid:3331452.

LI, H., ZHANG, S., 2002. In vitro cytotoxicity of the organophosphorus insecticide methylparathion to FG-9307, the gill cell line of flounder (Paralichthys olivaceus). Cell Biology and Toxicology, vol. 18 , no. 4 , pp. 235-241.

MARTINS, N.D., COLVARA, W.A., RANTIN, F.T. and KALININ, A.L., 2011. Microcystin-LR: how it affects the cardio-respiratory responses to hypoxia in Nile tilapia, Oreochromis niloticus. Chemosphere, vol. 84, no. 1, pp. 154-159. http://dx.doi.org/10.1016/j. chemosphere.2011.02.016. PMid:21382636.

MATAQUEIRO, M.I., NAKAGHI, L.S.O., SOUZA, J.P., CRUZ, C., OLIVEIRA, G.H. and URBINATI, E.C., 2008. Histopathological changes in the gill, liver and kidney of pacu (Piaractus mesopotamicus, Holmberg, 1887) exposed to various concentrations of trichlorfon. Journal of Applied Ichthyology, vol. 25 , no. 1 , pp. 124-127. http://dx.doi.org/10.1111/j.14390426.2008.01160.x.

MONTEIRO, D.A., ALMEIDA, J.A., RANTIN, F.T. and KALININ, A.L., 2006. Oxidative stress biomarkers in the freshwater characid fish, Bryconcephalus, exposed to organophosphorus insectice Folisuper 600 (methyl parathion). Comparative Biochemistry and Physiology. Toxicology \& Pharmacology : CBP, vol. 143, no. 2, pp. 141-149. PMid:16546452.

MONTEIRO, D.A., RANTIN, F.T. and KALININ, A.L., 2009. The effects of selenium on oxidative stress biomarkers in the freshwater characid fish matrinxã, Brycon cephalus (Günther, 1869) exposed to organophosphate insecticide Folisuper $600 \mathrm{BR}^{\circledR}$ (methyl parathion). Biochemistry and Physiology. Toxicology \& Pharmacology: CBP, vol. 149, no. 1, pp. 40-49. PMid:18655848.

PROTAS, L.L. and LEONTIEVA, G.R., 1992. Ontogeny of cholinergic and adrenergic mechanisms in the frog (Rana temporaria) heart. The American Journal of Physiology, vol. 262, no. 1, Pt 2, pp. R150-R161. PMid:1310237.

REZENDE, T., 2006. Alterações morfofuncionais e metabólicas no teleósteo Matrinxã de água doce Bryconcephalus (Ghünter, 1869) exposto ao organofosforado metil paration (Folisuper $\left.600{ }^{\circledR}\right)$. São Carlos: Departamento de Fisiologia, Universidade Federal de São Carlos, 79 g. Masters Dissertation in Physiology.

RODRIGUES, B.N. and ALMEIDA, F.L.S., 2005. Guia de herbicidas. 5th ed. Londrina: Grafmark. 592 p.

ROWE, C.L., HOPKINS, W.A. and BRIDGES, C.M., 2003. Physiological ecology of amphibians in relation to susceptibility to natural and anthropogenic factors. In: LINDER, G., KREST, S.K. and SPARLING, D.W., eds. Amphibian decline: an integrated analysis of multiple stressors effects. Raleigh: SETAC Press. 345 p.

TAYLOR, S.K., WILLIAMS, E.S. and MILLS, K.W., 1999. Effects of malathion on desease susceptibility in wood house's toads. Journal of Wildlife Diseases, vol. 35, no. 3, pp. 536-541. http://dx.doi.org/10.7589/0090-3558-35.3.536. PMid:10479088.

VIEIRA, C.A., TOLEDO, L.F., LONGCORE, J.E. and LONGCORE, J.R., 2013. Body length of Hylodes cf. ornatus and Lithobates catesbeianus tadpoles, depigmentation of mouthparts, and presence of Batrachochytrium dendrobatidis are related. Brazilian Journal of Biology = Revista Brasileira de Biologia, vol. 73, no. 1, pp. 195-199. http://dx.doi.org/10.1590/S1519-69842013000100021. PMid:23644802.

YU, F., WANG, Z., JU, B., WANG, Y., WANG, J. and BAI, D., 2008. Apoptotic effect of organophosphorus insecticide chlorpyrifos on mouse retina in vivo via oxidative stress and protection of combination of vitamins $\mathrm{C}$ and E. Experimental and Toxicologic Pathology, vol. 59, no. 6, pp. 415-423. http://dx.doi.org/10.1016/j. etp.2007.11.007. PMid:18222074. 